\section{Public Health and Agriculture}

IN his address to the Farmers' Club on February 3, Sir John Orr further expounded his views on the necessity for a national food policy (see NATURE of November 16, p. 771). The powers now given to marketing boards carry grave responsibilities; if fully used, 7 per cent of the population would control the remaining 93 per cent ; therefore those exercising control must think not only of the wholesale price that will make farming remunerative; but also of the retail price within the reach of consumers. The Market Supply Commission is considering food supplies from all three points of view-consumers', exporters' and producers'. The food question has been affected by new scientific discoveries, by our greatly increased productive capacity, and by the world economic crisis. Under-consumption by the poorer classes, with its sequelce, stunted growth, illhealth and poor physique, must be rectified by increases in their dietary of at least 12-25 per cent for dairy produce, vegetables, fruit and meat. Low consumption is due both to poverty and to ignorance. Ten per cent ( $4 \frac{1}{2}$ millions) of our population spend on an average only $4 s$. a head a week on food, and the total income of these families is only 10s. a head a week. To meet the extra consumption required, the necessary foodstuffs must be made available to the poor at prices lower than the present retail prices. But the furmers are justly asking for higher prices for their produce. How can both of these opposing needs be satisfied?

SIR JoHN ORR thinks there are two ways of dealing with the problem. Distribution costs must be lowered, and the Treasury, after partly recouping itself from ear-marked tariff revenues, must find the difference. Opposition to State expenditure on great schemes of social welfare, like sanitation and watersupplies, housing and unemployment, has always been strong when the reformative measures were proposed; but in all cases the subsidies given have been justified by results. Both health and a prosperous countryside can be bought by spending money on a national food policy. The discussion on Sir John Orr's address evoked much sympathy from his audience, although it failed to elicit any constructive suggestions. Lord Bledisloe stated that, during his tenure of office as Governor-General of New Zealand, he had ascertained that about 60 per cent of the inmates of public hospitals and similar institutions had suffered from under-nutrition. Several speakers disapproved of a State subsidy as part of a permanent policy, but only one voice-that of a milk-distributor -was raised against the proposal to reduce distribution costs. Lord Radnor, however, pointed out that hitherto no courage had been shown in tackling this important problem. He suggested, as a tertium quid, a general increase in the purchasing power of the nation, but no one supported him. It louks, therefore, as if considerable difficulty will be found in arranging a satisfactory 'marriage allowance' for the projected union of public health and agriculture.

\section{Dangers of Modern Civilisation}

Crvilisation and its dangers formed the subject of a recent address by Prof. $H$. E. Armstrong to the Lancaster Society, the occasion being the delivery of the third Frankland Lecture. Reviewing the chemical foundations of the Industrial Revolution, he laid emphasis on the part played hitherto by coal, and on the necessity of preparation for the coming exhaustion of coal supplies, possibly not more than two centuries hence. Few to-day realise what coal means to them, or they would not use it thoughtlessly; they must take care for the morrow, and efforts should be directed not to employing more miners but to economising the use of coal. The 1851 Exhibition was the first witness to other nations of the fruits of the use of coal ; but thereby the jealousy of other countries was excited, and then the engineers began to sell their machines abroad for others to copy, if not improve. They could not both have their cake and eat it unless in some way more cake were provided. Commercial war reigns everywhere; and this, the main problem of to-day, is brought upon them by the advance and spread of knowledge, especially by their power to use it. Insular conservatism is still a hindrance to progress; too often knowledge is ignorantly put aside, and management placed in uninformed hands. "Probably we are at the most perilous period in the history of our country, if not of the world," said Prof. Armstrong, "with little time to look around and put our house in order." Civilisation is fast becoming developed, if not organised, to promote the survival of the unfit. We are already in the position, owing to the art of scientific discovery and invention, of enjoying much more than before without striving; and he reminded his audience that man must either strive or degenerate.

INTELLECTUALLY, morally and physically, declared Prof. Armstrong in his lecture, man is being debased by his own inventions. The 'pictures', the wireless, cigarette smoking, and the aimless use of motor-cars all received their due meed of his disapproval ; so also did the schools, the universities, the classical (or closed) mind, and the mechanism of society. Nevertheless, it must be admitted that Prof. Armstrong generally hits a nail on the head, even though he is apt to use a steam-hammer for the operation. It is true enough that the function of the schools should be to give training in the art of understanding; not merely to impart knowledge. It is likewise true that men who have no understanding of the modern world cannot train for a service of reasoned intelligence. Wherefore, he claims, we must now place the schools in charge of men of charitable mind, men who will seek to evoke an understanding of the world in their pupils, that they may be enabled with some degree of thoughtfulness to do their duty with efficiency. It is impossible, said Prof. Armstrong, to overrate the danger arising from our failure to place general education on a scientific basis. Democracy is fast being made impossible by the one-sided application of the skill of the few; it can be saved from an early downfall only by an effective general spread of 
knowledge, and in particular of the art of using it thoughtfully and with set purpose. A difficulty will be to find teachers; men of action and ability are too much in demand for commercial or industrial posts. Teaching, in the main, is missionary service. Prof. Armstrong looks to the universities to break a vicious circle; but at present they are "so steeped in professionalism that they are of little use to the ordinary world ; they neglect general education on behalf of so-called research". We are entirely with Prof. Armstrong in his plea for a wider spread of knowledge, but he will forgive us for reminding him that we cannot both have our cake and eat it unless in some way we provide more cake.

\section{Dr. C. V. Drysdale, C.B., C.B.E.}

THE thirteenth Duddell Medal of the Physical Society was presented on February 7 to Dr. C. V. Drysdale, who is distinguished for his outstanding work in connexion with electrical and optical instruments. Dr. Drysdale was responsible for the design of the first accurate single-phase standard wattmeters in 1901, following them immediately by the first double wattmeters for polyphase measurements, and a few years later by accurate phase-shifting transformers for wattmeter and supply meter testing. In 1909 he adapted the phase-shifting transformer to the design of the first alternating and direct current potentiometer, and devised a vibration galvanometer and low inductance resistance standards which enables that instrument to be used for standardising purposes as well as for general testing, applying it particularly to transmission in telephone circuits. He was also responsible for other electrical standardising apparatus. In 1899, he took charge of the Electrical Engineering and Applied Physics Department of the Northampton Institute, Clerkenwell, and in the following year started the first Technical Optics Department at the Northampton Institute, with a lens grinding workshop. Then came a period of active research in optics, and including the design of lens systems, a universal optical bench for the rapid testing of spherical and cylindrical lens, etc.

Dr. DRYSDale was president of the Optical Society in 1904. In 1915 he entered into partnership with $\mathrm{Mr}$. H. Tinsley for the production of instruments for the War, but at the end of 1917 he was called to the Admiralty Experimental Station at Harwich for antisubmarine research, in the course of which he devised sensitive A.c. relays, a system of 'leader gear' for guiding ships along submarine cables, and various acoustic devices, some of which were described in his Kelvin Lecture to the Institution of Electrical Engineers in 1920. From 1921 until 1929 he was superintendent of the Admiralty Research Laboratory at Teddington. During this time he collaborated with Mr. A. C. Jolley in writing a book on "Electrical Measuring Instruments" ; he also edited the Journal of Scientific Instruments from 1925 until 1928. Dr. Drysdale held the appointment of director of scientific research to the Admiralty from 1929 until 1935, when he retired.

\section{Earth-Tremors in Montserrat}

Fon some time, according to The Times of February 7, earth-tremors have been occurring in Montserrat, one of the Leeward Islands. The subject having been referred to it by the Colonial Secretary, the Royal Society has recommended that an expedition should be sent to the Island to make a careful study of the tremors, and has undertaken to organise it and contribute the sum of $£ 300$ towards the cost. Since its discovery in 1493, Montserrat has shared to some extent in the destructive earthquakes of neighbouring islands, especially in those of Antigua in 1690, 1785, 1831 and 1874, and of Guadeloupe in 1843. In 1897-99, it was, however, visited by four semidestructive earthquakes (intensity I., Milne scale), the origins of which must have been within, or close to, the Island. Whether the recent tremors are the forerunners of another earthquake of the same type or of an eruption of the Soufrière, or merely an isolated series of slight earthquakes, would be determined effectively by the erection of portable tremo. meters, such as are used on similar occasions in Japan, at four stations in different parts of the Island. From the duration of the preliminary tremors, it would be possible to determine the surface position and depth of the focus of every earthquake recorded at all four stations. The results so obtained could not fail to be of value. At the same time, they might tend to allay anxiety in the Island or to suggest precautions for the future.

\section{Palæolithic Types in the American Stone Age}

Ar the St. Louis meeting of the American Associa. tion for the Advancement of Science on December 30January 4, Prof. E. B. Renaud, of the University of Denver, reported the discovery of a large number of stone implements by the Denver University Archæo. logical Survey of the State of Wyoming in the summer of last year. This survey is part of a comprehensive scheme initiated by Prof. Renaud for the inspection and, where feasible, investigation of the archæological sites of Colorado and adjacent States of the south. west, which has now been in progress for some years, and has already achieved some important results. The present find, according to a report circulated by Science Service, Washington, was made in a series of what Prof. Renaud describes as river terraces along the valley of Black's Fork, in south-western Wyoming, and consists of tools, rejects, scraps and pebbles numbering nearly eleven hundred in all. The principal interest of the discovery, however, lies in the fact that Prof. Renaud has classified the imple. ments into five groups, which correspond to the sequence of European palæolithic cultures, Chellean, Acheulean, Mousterian, etc. They are also said to correspond with the stone age implements of the Nile Valley. Prof. Renaud, in stating that this is the first time such a complex of prehistoric stone industry has come to light in North America, regards it as possible that the discovery "may be very significant". In the absence of more precise data and the verdict of geologists and palæontologists, which he awaits, it is not possible to arrive at a critical estimate of 